\title{
Tam Sayıların Öğretiminde Karikatürlerle Zenginleştirilmiş Eğitsel Matematik Hikâyelerinin Kullanılmasının Öğrencilerin Akademik Başarısına Etkisi*
}

\author{
The Effect of Using Educational Mathematics Stories Enriched \\ with Cartoons on Teaching Integers to Student's Mathematics \\ Achievements*
}

\author{
Elif ÜNÜVAR ${ }^{a}$, Sevda BARUT'b
}

Öz

Matematikte kullanılan sayı sembolleri geçmișten günümüze gelișip farkılașmıș: insanlar ve kavimler arasındaki ilișkiler artıp sosyal hayat geliştikçe farklı sayı sistemleri oluşturulmuştur. Günümüzden yaklaşık 2000 yıl önce doğal sayılar kümesi günlük yașam problemlerini çözmede yetersiz kalmıș ve tam sayılar kümesi ortaya çıkmıștır. Günümüz eğitim sisteminde öğrencilerin, tam sayılar kümesini kavramsallaştıabilmesi ve uygulayabilmesi; hem matematik müfredatındaki ardışık konularda, hem de diğer disiplinlerdeki ilişkili uygulamalarda önemli bir intiyaçtır. Erken çocukluk döneminden itibaren ilerleyen tüm eğitim süreçlerinde kullanılabilecek hikâyeler, öğrencilerin bilgiyi yapılandırmalarını ve basitlestirebilmelerini sağlamak amacıyla eğitsel olarak kullanılabilecek araçlardır. Karikatürler de kısıtı ders süresinde öğrencinin derse ilgisini çekmek, dikkatini toparlamak ayrıca keşfetme, sorgulama, düşünme yeteneklerini geliştirmede kullanılan araçlardır. Çalıșmanın amacı, eğitsel matematik hikâyeleri ve mizah içerikli karikatürlerin tam sayılar konusunun öğretiminde kullanılmasının; öğrencilerin akademik bașarılarına etkisinin belirlenmesidir. Araștırmanın çalışma grubunu 2017-2018 eğitim öğretim yılında Antalya'nın Kepez ilçesindeki bir devlet ortaokulunda öğrenim gören toplam 54 6. SInıf öğrencisi oluşturmaktadır. Çalışmada ön test-son test kontrol gruplu yarı deneysel desen kullanıımışır. Araştırmada nicel verilerin toplanması amacıyla "Tam sayılar Başarı Testi" kullanılmıștı. Yapılan analiz sonuçlarına göre bağımsız iki örneklem $t$-testinde $t$ istatistiği 4.49, $p$ olasılık değeri .00 olarak bulunmuștur. Eğitsel matematik hikâyeleri ve mizah içerikli karikatürlerin, tam sayılar konusunun öğretiminde kullanılmasının, öğrencilerin akademik başarılarını anlamlı şekilde arttırdığı görülmüştür.

Anahtar Kelimeler: Akademik Başarı, Hikâye, Karikatür, Tam Sayılar

Abstract

About the Article

Number symbols which is used in mathematics have developed and differentiated from past to present; as the relations between people and tribes increase and social life improves, different number systems are created. About 2000 years ago natural number cluster was inadequate in solving daily life problems and integer numbers has emerged. In today's education system, students' ability to conceptualize and implement integers is an important need for both consecutive subjects in mathematics curriculum and related practices in other disciplines. Stories that can be used in all educational processes starting from early chilhood are educational tools that can be used to enable students to structure and simplify information. Cartoons are also tools used to attract the attention of the students to the subject in the course of limited lesson, focus their attention also develop their ability to explore, question and reason. This study aims to determine the effects of using educational mathematical stories and humorous cartoons on teaching integers to student's academic achievement. The sample consist of 54 students from 6 grade of a state school at Kepez, Antalya in the 2017-2018 academic year. In the study, quasi-experimental pre test-post test control grouped design is used. In order to collect quantitative data Integer Success Test is used. t statistic was found as 4.49 and p probability value as .00 in t-test. According to the results of analysis it was determined that the use of educational mathematics stories and humorous cartoons significantly increased student's academic success.

\section{Makale Hakkında}

Tür: Araştırma

Geliş Tarihi: 13 Şubat 2020

Kabul Tarihi: 27 Haziran 2020

Yayın Tarihi: 4 Temmuz 2020

DOI

Sorumlu Yazar

Elif ÜNÜVAR

Milli Eğitim Bakanlığ

Antalya / Türkiye

E-posta: elif_unuvaro4@hotmail.com

Keywords: Academic Achievement, Cartoons, Integers, Storytelling

\section{Önerilen APA Atıf Biçimi / Suggested APA Citation}

Ünüvar, E., \& Barut, S (2020). Tam sayıların öğretiminde karikatürlerle zenginleştirilmiş eğitsel matematik hikâyelerinin kullanımasının öğrencilerin akademik başarısına etkisi. Academy Journal of Educational Sciences, 4(1), 45-52. http://dx.doi.org/10.31805/acjes.688801

Bu makale birinci yazarın yüksek lisans tezinin bir bölümünden yararlanılarak üretilmiştir.

This article was produced from a part of the first author's master's thesis.

aElif ÜNÜVAR-ORCID: https://orcid.org/0000-0002-1204-3556

Milli Eğitim Bakanlığı, Perihan-Esat Aral Ortaokulu, Antalya, Türkiye. E-posta: elif_unuvaro4@hotmail.com

Ministry of National Education, Perihan-Esat Aral Middle School, Antalya, Turkey. E-mail: elif_unuvaro4@hotmail.com 


\section{Giriş}

Kendine özgü amaç ve yöntemleriyle entelektüel bir uğraş olan matematik, bunun yanı sıra insanlık tarihinin her döneminde ve tüm uygarlıklarda sanat, bilim, endüstri, tarım gibi yaşamın birçok alanında etkili bir araç olmuştur (Yıldırım, 2017). Günümüzde de toplumların başarısı ve kalkınmışlığı, iyi eğitilmiş toplum bireyleri sayesinde sağlanmaktadır. Bireyin içinde yaşadığı toplumu, yakın çevresini ve dünyayı anlamlandırmasında da önemli bir araç olan matematik, bireye beceri ve estetik kazandıran, muhakemeyi ve yaratıcı düşünceyi geliştiren, bilginin işlenmesiyle oluşturulmuş sembolik bir dildir (Baykul, 2009). Başta teknoloji olmak üzere, diğer tüm bilimler arasında önemli bir yere sahip olan matematik; toplum bireylerinin çağın gereksinimlerine uygun bilimsel düşünme becerilerini geliştirip, bu becerilerini yaşamın gerekli alanlarında uygulayabilmeleri için vazgeçilmez ve değerli bir uğraştır (Işık, Çiltaş ve Bekdemir, 2018). Matematiğin hem bireysel gelişime hem de toplumsal ilerlemeye katkısı nedeniyle, matematik öğretimi okul öncesinden itibaren önem kazanmaktadır.

Bireylere kendi yaş ve düzeyine uygun şekilde matematik bilgi ve becerileri kazandırmak ve gerekli durumlarda bu birikimlerini kullanabilmelerini sağlamak, kişilere kendi sınıf düzeylerine uygun olarak kazandırılacak matematik öğretimi ile mümkün olmaktadır (Altun, 2015).

Geçmişten günümüze gelişerek biriken matematik bilgisinin bugün bireylere kazandırıması amacıyla düzenlenen formal eğitim sürecinin önemli bir parçası da ilköğretim ikinci kademe matematik öğretimidir. lilköğretim ikinci kademe matematik öğretimi üzerine yapılan araştırmalar; öğrencilerin temel matematiksel kavramları anlamlandırmada, birbirleri ile ilişkilendirmede ve matematikteki soyut kavramları somutlaştırmada zorluk yaşadıklarını göstermektedir (Akgün, 2009; Anapa Saban ve Bağdat, 2014; Çakmak Gürel ve Okur, 2017; Kaya, 2017; Şengül ve Cantimer, 2018; Tekerek ve Cebesoy, 2017). Öğrencilerin büyük çoğunluğu tam sayı kavramını zihninde doğru biçimde yapılandıramamaktadır (Şengül ve Cantimer, 2018). Yine öğrencilerin büyük çoğunluğu negatif tam sayılarla çıkarma işleminde zorlanmakta, bu durum diğer disiplinlerdeki başarılarını da olumsuz etkilemektedir (Tekerek ve Cebesoy, 2017). Öğrencilerin negatif ve pozitif tam sayılara yönelik tahmin stratejilerinde negatif tam sayı tahminleri pozitif tam sayı tahminlerine göre daha az başarılıdır (Yoong ve Booth, 2015). Öğrenciler eksi (-) işaretini anlamlandırmada, eksi işaretinin günlük hayattaki karşıığını kavramsallaştırmada, negatif tam sayılarla çıkarma işlemi yapmada ve tam sayıları sıralamada sıkıntılar yaşamaktadır (Erdem, Başıbüyük, Gökkurt, Şahin ve Soylu, 2015: Yenilmez ve Bağdat, 2014).

Matematiğin bilim, teknoloji ve birçok meslek alanında kullanılması yetişkinleri matematiğe yöneltse de bu çocuklar için çok uzak bir hedeftir ve çocuklar üzerinde kısa süreli motivasyonlar daha etkilidir. Çocukları matematik öğrenmeye sevk eden şeyler ise süreçten ve sonuçtan zevk almaktır (Skemp, 1986).

Öğrenci öğrenme sürecinde yeni bir bilgi kazanırken bunu zihninde oluşan şemalar yardımıyla kendisi yapabilir. Öğretmen bu süreçte ancak öğrencinin kavramları kazanmasına yardımcı olup rehberlik edebilir. Bu yüzden öğretim sürecinde öğrencinin kendisinin öğrenmesi esas alınmalı, matematikteki genellemeleri ve işlem yollarını kendilerinin oluşturmasına fırsat verilmelidir (Baykul, 2009). Ayrıca öğrenim sürecinde öğrencilerin duyu organları yoluyla edindikleri uyarıcıları anlamlandırmaları ile oluşan algı, uyarıcı özelliklerinden fazlasıyla etkilenmektedir. Bununla birlikte öğrenme sürecinde fazla miktarda uyarıcıya maruz kalan birey, bu uyarıcılardan ancak seçtiklerini algılayabilmektedir. Bu seçilen uyarıcılar ise, en çok dikkat çekenlerdir (Ülgen, 2006).

Hikâye anlatımının eğitimsel doğası bilgiyi anlatmak ve anlayışı paylaşmaktır. Erken çocukluk döneminden itibaren ilerleyen tüm eğitim süreçlerinde ve farklı alanlarda kullanılabilecek hikâyeler, öğrencilerin dil geliş̧iminin yanı sıra bilgi sahibi olmalarını, karmaşık konularda bilgiyi yapılandırmalarını ve basitleştirebilmelerini sağlamak amacıyla eğitsel olarak kullanılabilir (Wang ve Zhan, 2010). Hikâyeye dayalı öğretimde, öğrenme ortamında öğrenciler kendilerini motive eden ve eğlendiren hikâyelerin içerisindeki temel kavramları ortaya çıkarıp analiz edebilmekte, kavramlarla ilgili farklı etkinlikler yapabilmekte, kendi düşüncelerini ifade etme ve konu üzerinde tartışma imkanı bulabilmektedirler. Bu yöntem öğrencilerin sınıf içi etkileşimlerinin artmasını sağlayıp, kendi öğrenmelerinden sorumlu olmalarını da sağlamaktadır (Demircioğlu H., Demircioğlu G. ve Ayas, 2006). Öğretim sürecinde hikâyeler anlatıırken öğrenciler hem kavramlarla hem de hikâyedeki karakterlerle ilgili sorular sormakta ve merakla hikâyenin sonunu beklemektedirler. Bu yüzden de hikâyeler öğrencilerin hatırlamalarını kolaylaştırmaktadır (Demircioğlu, Erol ve Kurnaz, 2017). Hikâye öğretimi ile öğrenciler müfredatın amaçları ötesinde matematiksel bilgileri merak etmekte, ders planında kaybolan ayrıntıları öğrenebilmekte ve hikâyeler onları matematik hakkında daha fazla araştırmaya yönlendirmektedir. Ayrıca öğrenciler öyküleri değerli birer öğrenme aracı olarak görmekte ve bu sayede gerçekten anlayarak matematik anlayışlarını geliştirebilmektedirler (Toor ve Mgombelo, 2015). Öğretimde hikâyeleştirme yönteminin kullanılması, öğrencilerin yaratıcı düşünme düzeyleri üzerinde de olumlu etkiye sahiptir (Yiğit ve Erdoğan, 2018).

Öğrencilere kazandırılmak istenen davranışlara uygun olarak geliştirilen mizah; düşünme ve sorgulamayı arttırıcı, kaygı düzeyini azaltıcı bir etkiye sahiptir (Torrok, Mcmorris ve Lin, 1999). Kazanımlara uygun olarak düzenlenmiş karikatürler farklı disiplinlerde farklı konularda öğrencilerin keşfetme, sorgulama, düşünme yeteneklerini geliştirecektir. Mizahi içeriğin içindeki kavramsal yönü anlamaya çalışan öğrenciler zihinsel bir etkinlik içerisine girecek ve düşünmeye sevk edilmiş olacaklardır. Kısıtlı ders süresinde öğrencinin derse ilgisini çekmek ve dikkatini toparlamak için de karikatürler kullanılabilecek araçlardır.

Karikatürün öğretim sürecinde kullanılması öğrencilerin kavram yanılgılarını gidermede etkili bir yöntemdir (Kaplan, Altaylı ve Öztürk, 2014). Karikatür tekniği ile öğretim; farklı öğrenme düzeylerine sahip öğrencilere uygun öğrenme fırsatları sunmakta, tüm öğrencileri eğitim sürecine katacak kadar dikkat çekici ve güdüleyici olmaktadır. Ayrıca konuya olan ilginin sürekliliğini sağlamakta ve dersi eğlenceli hale getirmektedir (Çetin, 2012).

Literatürde yapılan çalışmalar incelendiğinde öğretimde karikatür ve hikâye ile öğretim yöntemlerinin ayrı ayrı kullanıldığı (Demircioğlu, Erol ve Kurnaz, 2017; Kaplan, Altaylı ve Öztürk, 2014; Katipoğlu, Eken ve Körbay, 2017), ancak iki yöntemin birlikte uygulanmadığı görülmektedir. Bu nedenle bu araştırmanın amacı, ortaokul 6. sınıf öğrencilerine tam sayılar konusunun öğretiminde kullanılan eğitsel matematik 
hikâyeleri ve mizah içerikli karikatürlerin; öğrencilerin akademik başarılarında oluşturacak farklılıkların araştırılmasıdır. Bu amaç çerçevesinde "Eğitsel matematik hikâyelerinin ve mizah içerikli karikatürlerin birlikte kullanıldığı deney grubu öğrencileri ile sunuş yöntemi ile ders anlatımı yapılan kontrol grubu öğrencilerinin 'Tam Sayılar Başarı Testi' ön test ve son test akademik başarı puanları arasında anlamlı bir farklılık var mıdır?" sorusu cevaplanmıştır.

\section{Yöntem}

\section{Araştırmanın Modeli}

Bu çalışmada deney ve kontrol gruplu ön test-son test yarı deneysel desen kullanılmıştır. Çalışmada, 6. sınıf tam sayılar konusu kazanımlarının öğretiminde deney grubu öğrencilerinde eğitsel matematik hikâyeleri ve mizah içerikli karikatürler kullanılıken, kontrol grubu öğrencilerine sunuş yöntemi ile geleneksel ders anlatımı yapılmıştır. Deney ve kontrol grubu başarı testi sonuçları arasında anlamlı farklılıklar olup olmadığı araştırılmıştır.

\section{Çalışma Grubu}

Araştırmanın çalışma grubunu 2017-2018 eğitim öğretim yılında Antalya'nın Kepez ilçesindeki bir devlet ortaokulunda öğrenim görmekte olan toplam 54 6. sınıf öğrencisi oluşturmaktadır. Araştırmanın yapılabilmesi için uygulamaya yönelik gerekli izinler alınmıştır (Etik Kurul raporu, MEB izni vs.)

\section{Uygulama Süreci}

Çalışmanın uygulaması 2017-2018 eğitim-öğretim yılının ikinci döneminde toplam 15 ders saati süresinde yapılmıştır. Uygulama için kullanılacak karikatürler ve eğitsel matematik hikâyeleri birinci yazar tarafından hazırlanmıştır. Uygulanacak karikatürlerin ve hikâyelerin kazanımlara ve öğrencilerin gelişimsel süreçlerine uygunluğu için; Matematik, Görsel Sanatlar ve Türkçe olmak üzere farklı branş öğretmenlerinden ve Ilköğretim Anabilim Dalı Matematik Eğitimi Bölümü öğretim üyelerinden görüş alınmıştır. "Tam Sayılar" konusu ile ilgili kazanımlara ait ders saatleri Tablo 1 de verilmiştir:

Tablo 1. "Tam Sayılar" konusu kazanımları ve ders saati süreleri

\begin{tabular}{lr}
\hline Kazanım & Ders Saati \\
\hline Tam sayıları yorumlar ve sayı doğrusunda gösterir. & 2 \\
\hline $\begin{array}{l}\text { Bir tam sayının mutlak değerini belirler ve anlam- } \\
\text { landıır }\end{array}$ & 3 \\
\hline
\end{tabular}

Tam sayıları karşılaştırır ve sıralar. 2

Tam sayılarla toplama ve çıkarma işlemlerini yapar. ilgili problemleri çözer.

Tam sayılarda çıkarma işleminin eksilenin ters işaretlisi ile toplamak anlamına geldiğini kavrar

Toplama ișleminin özelliklerini akıcı işlem yapmak için birer strateji olarak kullanır.

Birinci yazar tarafından hazırlanan karikatürlerin ve eğitsel matematik hikâyelerinin içerdiği çizimler, bilgisayarda ve tablette farklı çizim programları ile yapılmıştır. Eğitsel matematik hikâyeleri, "Şipşak" adında bir kahramanın günlük hayatta karşılaştığı bir sorun ya da düşünce üzerinden mer- ak hissinin oluşması ile başlatılmış; sonrasında kahramanın kendini sayılar dünyasında bulması ile hikâye devam etmiştir. Hikâyeler, kahramanın sayılar dünyasında sayılarla tanışıp konuşması; onların maceralarına ortak olması ve onların dünyasını keşfetmesi ile şekillenmiştir.

Uygulama sürecinde, gerek deney gerekse kontrol grubuna aynı matematik öğretmeni tarafından öğretim yapılmıştır. Hikâyeler deney grubu sınıfındaki her öğrenciye dağıtılmış ve öğrencilerden birinin sesli okuması istenmiștir. Hikâye okunurken belli aralıklarla ve hikâye sonunda öğrencilere sorular sorulmuş, sınıfta bir tartışma ve fikir alışverişi ortamı oluşturulmuş, kavramlara ve genellemelere öğrencilerin ulaşması hedeflenmiştir. Daha sonra konuya ilişkin karikatürler yine her öğrenciye dağıtılmış ve öğrencilerden karikatürün vermek istediği matematiksel durumlara uygun işlemleri gerçekleştirmeleri istenmiştir.

Uygulama sürecinde; 'Şipşak Sayılar Dünyasında' adlı hikâye çalışması ile öğrencilerin tam sayıları yorumlayabilmesi ve sayı doğrusunda gösterebilmeleri amaçlanmıştır (Ünüvar, 2019).

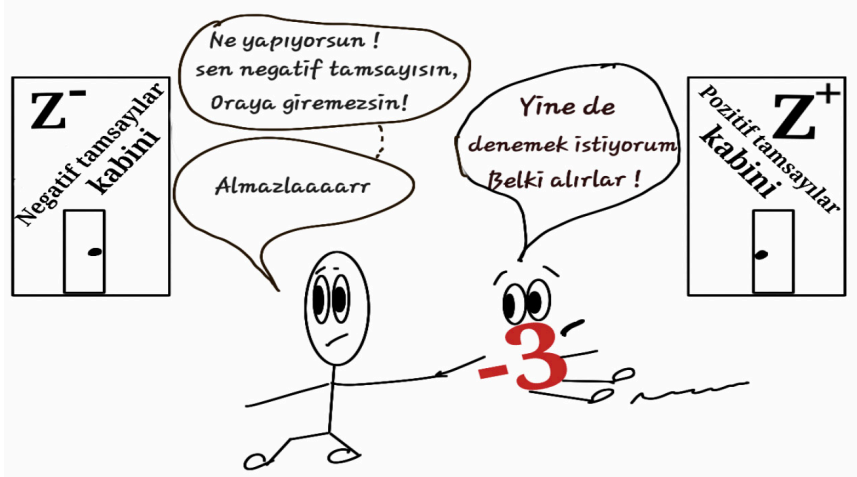

Şekil 1. "Negatif mi Pozitif mi?" Karikatürü

Şekil1'de verilen karikatür çalışması ilgili hikâye çalışmasından sonra öğrencilere dağıtılmış ve öğrencilere karikatürü yorumlamaları için çeşitli sorular sorulmuştur.

\section{- Karikatür bize nasıl bir mesaj vermektedir?}

- '-3' sizce de pozitif tam sayılar kabinine giremez mi?

- Negatif tam sayılar kabinine hangi sayıları yazabiliriz?

- Sizce negatif ve pozitif tam sayılar kabini sınırlı sayıda mı pozitif ve negatif tam sayıyı kabul etmektedir?

- o' । hangi kabin kabul edebilir?

- Negatif bir tam sayının pozitif tam sayılar kabinine girmesini sağlayabilir miyiz?

Sınıf içerisinde öğrencilerin sorulara verdikleri cevaplar ve kendi çıkarımları ile karikatürü yorumlamaları istenmiş, ardından konu ile ilgili matematiksel işlem soruları üzerinde çalışmalar yapılmıştır.

'Hadi Toplanalım' karikatürü ile öğrencilere negatif tam sayılar ve pozitif tam sayılar kümelerinin kavratılması hedeflenmiş, karikatür sınıfça incelenip yorumlandıktan sonra karikatürlerdeki matematiksel durumlara uygun hazırlanan 
çalışma soruları öğrencilerle birlikte çözümlenmiştir. Sıfırın ne negatif ne de pozitif tam sayılar kümesine ait olmadığının ve işaretsiz olduğunun öğretiminde 'Hayat Sana Güzel!' karikatürü, tam sayıların toplamaya göre terslerinin bulunmasında 'Hangimiz Ters?' karikatürü ve 'Ikimiz de Pozitifiz' karikatür çalışmaları kullanılmıştır.

Öğrencilerin bir tam sayının mutlak değerini belirleyip anlamlandırabilmeleri için 'Mutlak Değer Kabini' adlı hikâye çalışması kullanılmıştır. Hikâyede Şipşak karakteri mutlak değer kabini önünde sıralanıp tartışan sayıların konuşmalarına şahit olmakta ve ona eşlik eden -8 sayısı ile birlikte olanları yorumlamaktadır.

'Mutlak Değer Kabini' hikâye çalışmasının ardından 'Sadece Pozitif Olacaksın', 'Negatif Olmak Bana Göre Değil', 'Ne Kadar da Negatifsin' karikatür çalışmaları da kullanılmıştır.

Öğrencilere 'Tam sayıları karşılaştırır ve sıralar' kazanımının öğretiminde 'Tam Sayılar Minibüsü' hikâyesi kullanılmıştır. Hikâyede -8 ile birlikte tam sayılar minibüsüne binen Şipşak minibüste sayıların oturuş sırasına ve yanlış yerlere oturan sayıların birbiri ile tartışmalarına şahit olmaktadır. Hikâye çalışmasının ardından 'Hangimiz Daha Küçük?', 'Indir o Ayağını', 'En Büyük Negatif Tam Sayı' ve 'En Küçük Pozitif Tam Sayı' karikatürleri kullanılmıştır.

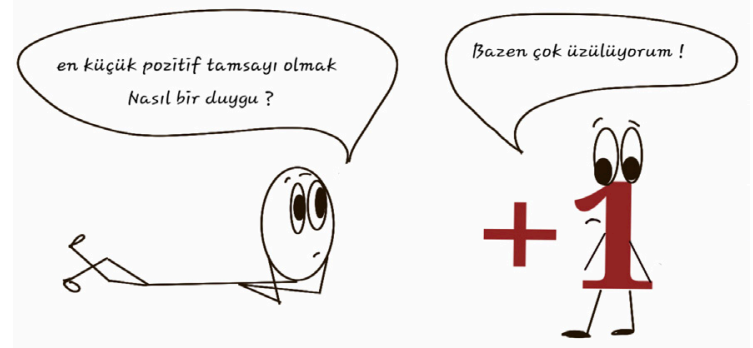

Şekil 2. 'En Küçük Pozitif' Karikatürü

Şekil 2' de verilen karikatür çalışması ile öğrencilerden karikatürü yorumlamaları istenmiş ardından öğrencilere tek basamaklı, iki basamaklı, üç basamaklı en büyük ve en küçük tam sayılarla ilgili sorular sorulmuştur. Karikatür üzerinde yorumlama ve tartışma yapıldıktan sonra ilgili matematiksel işlemler içeren çalışmalar yapılmıştır.

Tam sayılarla toplama çıkarma işlemi ve bu işlemlerin özellikleri ile ilgili kazanımların öğretiminde ise sırasıyla 'Tam Sayılar Toplama Binasında' ve 'Şipşak Çıkarma Binasında' hikâye çalışmaları ile birlikte 'Hadi Toplanalım', 'Sıfırı Üzmeyelim', 'Mutlak Değerini Al da Gel', 'Biz Aslında Kimiz?', 'Lütfen Daha Dikkatli Olalım' karikatür çalışmaları kullanılmıştır.

'Biz Aslında Kimiz?' karikatür çalışmasında; öğrencilere, tam sayılarla çıkarma işleminde negatif tam sayının işareti ile çıkarma işleminin işaretinin ayrımında farkındalık oluşturmak amaçlanmıştır.

Hikâye ve Karikatür çalışma örneklerine bu makalenin Ek kısmında yer verilmiştir.

\section{Verilerin Toplanması}

Deney ve kontrol grubu öğrencilerini belirlemek amacıyla üç 6. sınıf şubesine matematik başarı testi uygulanmış, ortalamaları birbirine en yakın iki grup deney ve kontrol gru- bu olarak belirlenmiştir. Çalışmada deney grubu öğrencileri 27 kiși, kontrol grubu öğrencileri de 27 kișidir. Araștırmada nicel verilerin toplanması amacıyla uygulanan "Tam Sayılar Başarı Testi", geçmiş yıllarda çıkmış Devlet Parasız Yatılı Bursluluk Sınavı (DPY) ve Ortaöğretim Kurumlar Sınavı (OKS) sorularından derlenerek oluşturulmuş; daha sonra uzman görüşü alınarak kazanımlara uygun olacak şekilde 20 çoktan seçmeli soru olarak düzenlenmiştir.

\section{Verilerin Analizi}

Süreç boyunca nicel veriler SPSS programının ara yüzüne aktarılmıştır. Hazırlanan Tam Sayılar Başarı Testinin Cronbach Alpha güvenirlilik katsayısı .71 olarak hesaplamıştır. Çalışma sonucunda elde edilen veriler analiz edilmeden önce, test sonuçlarının normal dağııma uygun olup olmadığını tespit edebilmek için Shapiro-Wilk normallik testi uygulanmış ve veri gruplarının çarpıklık basıklık değerleri incelenmiştir. Kerr, Hall ve Kozub (2002)'ye göre, çarpıklık ve basıklık değerlerinin kabul edilebilir sınırlar arasında, yani -1.96 ve +1.96 arasında olması verilerin normal dağılım gösterdiğini işaret etmektedir. Tüm istatistikler birlikte değerlendirildiğinde, verilerin normal dağılım gösterdiği tespit edilmiştir. Deney ve kontrol gruplarına uygulanan "Tam Sayılar Başarı Testi" ön test-son test puanlarına ilişkin anlamlı farklılıkların belirlenmesinde bağımlı ve bağımsız iki örneklem t-testi kullanılmıştır. Çalışmada p anlamlıık düzeyi \%5 olarak alınmıştır.

\section{Araştırmanın Etik Izinleri}

Bu araştırmanın planlanma, uygulama ve raporlama süreçlerinin tamamında "Yükseköğretim Kurumları Bilimsel Araştırma ve Yayın Etiği Yönergesi" kapsamında uyulması belirtilen tüm kurallara uyulmuştur. Yönergenin ikinci bölümü olan "Bilimsel Araștırma ve Yayın Etiğine Aykırı Eylemler" bașlığı altında belirtilen eylemlerden hiçbiri gerçekleștirilmemiştir. Akdeniz Üniversitesi Sosyal ve Beşeri Bilimler Bilimsel Araştırma ve Yayın Etiği Kurulunun 07.03.2018 tarih ve 15 sayılı toplantısında yapılan görüşmeler ve değerlendirmeler sonucunda çalışmanın içeriğinde ve uygulanmasında etik açıdan bir sakınca olmadığına oy birliği ile karar verilmiştir.

\section{Bulgular}

\section{Ön test-son test başarı testi puan karşılaştırmaları}

Deney ve kontrol gruplarına ait ön test ve son test başarı puan ortalamaları arasında fark olup olmadığını araştırmak için parametrik testlerden bağımsız iki örneklem $t$-testi kullanılmıştır. Aynı gruba ait ön test ve son test başarı puan ortalamaları arasında fark olup olmadığını araştırmak için ise bağımlı örneklem $t$-testi kullanılmıștır. Deney ve kontrol grubu varyanslarının eşitliğini araştırmak için ise Levene testi kullanılmıştır.

Tablo 2. Deney ve kontrol grubuna ait tam sayılar testi ön test başarı puanları karşılaştırması

\begin{tabular}{lrrrrrr}
\hline & $N$ & $X$ & $S D$ & $d f$ & $t$ & $p$ \\
\hline Deney Grubu & 27 & 19.44 & 8.35 & & & \\
\hline Kontrol Grubu & 27 & 22.40 & 9.44 & & -1.221 & .228 \\
\hline
\end{tabular}

Levene Testi $F$ istatistiği 1.418 olarak, olasılık değeri .23 olarak hesaplanmıştır. Ön test için deney grubu ve kontrol grubu varyanslarının eşit olduğu varsayımı kabul edilmiştir. Bu 
varsayım altında uygulanan bağımsız iki örneklem $t$ testinde $t$ istatistiği -1.22 olarak, olasılık değeri ise .228 olarak hesaplanmıştır. Olasılık değeri $(p=.228>$.05) deney grubu ve kontrol grubunun ön test sonuçları arasında anlamlı bir farklılık olmadığını göstermektedir. Bu sonuç, deney ve kontrol grubunun tam sayılar konusunda uygulama öncesi başarı düzeylerinin denk olduğunu gösterir.

Tablo 3. Deney ve kontrol grubuna ait tam sayılar testi son test başarı puanları karşılaştırması

\begin{tabular}{lrrrrrr}
\hline & $N$ & $X$ & $S D$ & $d f$ & $t$ & $p$ \\
\hline Deney Grubu & 27 & 45.92 & 13.51 & & & \\
\cline { 1 - 4 } Kontrol Grubu & 27 & 29.07 & 14.00 & & 4.498 & .000 \\
\hline
\end{tabular}

Son test için Levene Testi $F$ istatistiği .023 olarak, olasılık değeri 87 olarak hesaplanmıştır. Son test için deney grubu ve kontrol grubu varyanslarının eşit olduğu varsayımı kabul edilmiştir. Bu varsayım altında uygulanan bağımsız iki örneklem $t$-Testinde $t$ istatistiği 4.49 olarak, olasılık değeri ise .00 olarak hesaplanmıştır. Olasılık değeri $(p=.000<.05)$ deney grubu ve kontrol grubunun son test sonuçları arasında \%5 anlamlılık düzeyinde anlamlı bir farklıık olduğunu göstermektedir. Bu sonuç, tam sayılar konusunda deney grubunda yapılan uygulamanın kontrol grubunda yapılan geleneksel öğretime göre öğrencilerin başarısını arttırmada daha etkili olduğunu gösterir.

Tablo 4. Deney grubuna ait tam sayılar testi ön test ve son test başarı puanları karşılaştırması

\begin{tabular}{lrrrrrr}
\hline Deney Grubu & $N$ & $X$ & $S D$ & $d f$ & $t$ & $p$ \\
\cline { 1 - 4 } Ön test & 27 & 19.44 & 8.35 & & & \\
\cline { 1 - 3 } Son test & 27 & 45.92 & 13.51 & & 11.107 & .000 \\
\hline
\end{tabular}

Yapılan $t$-testi sonucunda hesaplanan olasılık değeri ( $p=$ $.000<.05$ ), deney grubu ön test ve son test başarı puanları arasında \%5 anlamlıık düzeyinde anlamlı bir fark olduğunu göstermektedir. Çalışma deney grubunun başarısını anlamlı bir şekilde arttırmıştır. Bu sonuç, tam sayılar konusunda deney grubunda yapılan uygulamanın öğrenci başarısını arttırdığını gösterir.

Tablo 5. Kontrol grubuna ait tam sayılar testi ön test ve son test başarı puanları karşılaştırması

\begin{tabular}{lrrrrrr}
\hline Kontrol Grubu & $N$ & $X$ & $S D$ & $d f$ & $t$ & $p$ \\
\cline { 1 - 4 } Ön test & 27 & 22.40 & 9.44 & & & \\
\cline { 1 - 3 } Son test & 27 & 29.07 & 14.00 & & 2.55 & .017 \\
\hline
\end{tabular}

Elde edilen olasılık değerine göre ( $p=.017<.05)$, kontrol grubu ön test ve son test başarı puanları arasında \%5 anlamlılık düzeyinde anlamlı bir fark olduğu belirlenmiştir. Sunuş yöntemi ile geleneksel ders anlatımı yapılan kontrol grubunun bașarısı anlamlı bir șekilde artmıștır. Bu sonuç, tam sayılar konusunda kontrol grubunda yapılan geleneksel öğretimin öğrenci başarısını arttırdığını gösterir.

\section{Tartışma ve Sonuç}

Çalışmada, 6. Sınıf öğrencilerine tam sayılar konusunun öğretiminde, deney grubu olarak belirlenen sınıfta eğitsel matematik hikâyeleri ve mizah içerikli karikatürler birlikte kullanılmış, kontrol grubunda ise geleneksel sunuş yöntemi ile ders anlatımı yapılmış ve uygulanan çalışmaların akademik başarıya etkisi araştırılmıştır.
Deney ve kontrol gruplarına uygulamadan önce ön test ve uygulama sonrası son test "Tam Sayılar Başarı Testi" uygulanmıştır. Deney ve kontrol gruplarının ön test sonuçlarında anlamlı bir farklıık bulunmadığı tespit edilmiştir. Iki grubun matematik başarısının denk olduğu söylenebilir. Son test sonuçlarında ise, deney grubu lehine anlamlı bir farklıık tespit edilmiştir. Eğitsel matematik hikâyeleri ve mizah içerikli karikatürler kullanılarak yapılan öğretimin geleneksel yönteme göre akademik başarıyı arttırmada daha etkili olduğu belirlenmiştir.

Deney ve kontrol grubunun ön test- son test veri analizi sonuçları ayrı ayrı incelendiğinde ise, hem deney grubunun hem de kontrol grubunun ön test-son test başarı puanları arasında anlamlı farkııık bulunmaktadır. Bu sonuca göre her iki grupta da öğrenme gerçekleştiği söylenebilir; ancak, başarı puanlarındaki artışa göre, deney grubunda uygulanan eğitsel matematik hikâyeleri ile mizah içerikli karikatürler tam sayılar öğretiminde çok daha etkili olmuştur.

Araștırmada elde edilen sonuçlar literatürde yapılan çalıșmalar ile paralellik göstermektedir. Literatürde, eğitim alanında farklı disiplinlerde yapılan hikâye çalışmaları incelendiğinde; hikâyelerin öğrencilerin kavramları günlük hayatla ilişkilendirip konuları anlamasını ve hatırlamasını kolaylaştırdığı, başarıyı arttırdığı ve hikâyelerin öğrencilerin yaratıcı düşünme düzeyleri üzerinde etkili olduğu belirlenmiştir (Demircioğlu, Erol ve Kurnaz, 2017; Pekmezci, 2014; Yiğit ve Erdoğan, 2008). Matematik öğretiminde hikâye kullanımının, öğrencilerin öğrenim sürecine katılmalarında ve onlardaki algıların ortaya çıkarılmasında önemli bir araç olduğu, hikâyelerin onları matematik hakkında daha fazla araştırmaya yönlendirdiği ve matematik anlayışlarını geliştirdiği tespit edilmiştir (Toor ve Mgombelo, 2015).

Literatürde farklı disiplinlerde yapılan karikatür çalışmalarında ise karikatür tekniğinin farklı öğrenme düzeyine sahip öğrencilere uygun öğrenme fırsatı sunduğu, derse ve konuya olan ilginin sürekliliğini sağladığı, öğrencilerin mevcut kavram yanılgılarını bilimsel olarak tartışmalarına olanak sağladığı sonuçlarına ulaşılmıştır (Çetin, 2012; Yavuz ve Büyükekşi, 2011). Katipoğlu, Eken ve Körbay (2017)'ın doğal sayılar konusunun öğretiminde mizah içerikli karikatürleri kullandıkları çalışmalarında; karikatürle öğretim, öğrencilerin başarısını arttırmada geleneksel yöntemlere göre daha faydalı bulunmuştur.

Matematik öğretiminde özellikle öğrencilerin zihinlerinde canlandırmakta zorlandıkları soyut kavramların somutlaştırılmasında, öğrencilerin daha fazla sorgulayarak öğrenmeleri, konular ve sorular üzerinde muhakeme yeteneklerini geliştirebilmeleri ve akademik başarılarını arttırabilmeleri için, eğitsel matematik hikâyeleri ve mizah içerikli karikatürler birlikte kullanılabilir.

Mevcut araştırma ortaokul 6. sınıf düzeyinde yürütülmüştür. Eğitsel hikâye ve karikatür çalışmaları ilköğretim ve ortaöğretim düzeyinde farklı sınıf seviyelerinde ve farklı öğrenme alanlarında uygulanabilir. Çalışma bir devlet okulunun iki farklı sınıfında sadece 15 ders saati süresince uygulanmıştır; yıllık planlarla uyumlu olacak şekilde hikâyeler ve karikatürlerle bir dönem ya da bir öğretim yılı boyunca uygulama yapılıp, uygulamanın etkileri farklı değişkenler açısından incelenebilir. Eğitsel matematik hikâyeleri animasyon ya da çizgi film formatına dönüştürülüp farklı öğrenme alanlarında uygulamalar yapılabilir. 


\section{Yayın Etiği Beyanı}

Bu araştırmanın planlanma, uygulama ve raporlama süreçlerinin tamamında "Yükseköğretim Kurumları Bilimsel Araştırma ve Yayın Etiği Yönergesi" kapsamında uyulması belirtilen tüm kurallara uyulmuştur. Yönergenin ikinci bölümü olan "Bilimsel Araștırma ve Yayın Etiğine Aykırı Eylemler" bașlığı altında belirtilen eylemlerden hiçbiri gerçekleştirilmemiştir. Akdeniz Üniversitesi Sosyal ve Beşeri Bilimler Bilimsel Araştırma ve Yayın Etiği Kurulunun 07.03.2018 tarih ve 15 sayılı toplantısında yapılan görüşmeler ve değerlendirmeler sonucunda çalışmanın içeriğinde ve uygulanmasında etik açıdan bir sakınca olmadığına oy birliği ile karar verilmiştir.

\section{Kaynakça}

Akgün, L. (2009). 8. sınıf öğrencilerinin sözel problemler ve değişken kavramı arasında ilişki kurabilme becerileri. Mersin Üniversitesi Eğitim Fakültesi Dergisi, 5(2), 275284.

Altun, M. (2015). Eğitim fakülteleri ve sınıf öğretmenleri için matematik öğretimi. Bursa: Aktüel Alfa

Anapa Saban, P. ve Bağdat, O. (2014). Illköğretim 8. sınıf öğrencilerinin cebirsel düşünme becerilerinin solo taksonomisi ile incelenmesi. International Journal of Social Science, 26, 473-496. doi: 10.9761/JASSS2364.

Baykul, Y. (2009). illköğretimde matematik öğretimi 6-8. sınıflar. Ankara: Pegem Akademi.

Çetin, E. (2012). Karikatürler ile zenginleştirilmiş fen ve teknoloji dersinin öğrenci başarısı ve tutumları üzerine etkisi (Yüksek lisans tezi), Selçuk Üniversitesi Eğitim Bilimleri Enstitüsü.

Çakmak Gürel, Z. ve Okur, M. (2017). 7. ve 8. sınıf öğrencilerinin eşitlik ve denklem konusundaki kavram yanılgıları. Cumhuriyet Uluslararası Eğitim Dergisi, 6(4), 479-507.

Demircioğlu, G., Kurnaz, B. ve Erol, T. (2017). Bağlam temelli yaklaşımın lise öğrencilerinin gazlar konusunu anlamaları üzerine etkisi. Eğitim ve Öğretim Araştırmaları Dergisi, 6(3), 161-174.

Erdem, E., Başıbüyük, K., Gökkurt, B., Şahin, Ö. ve Soylu, Y. (2015). Tam sayılar konusunun öğretiminde yaşanan zorluklar ve çözüm önerileri. Erzincan Eğitim Fakültesi Dergisi, 17(1), 97-117. doi: http: 10.17556/jef.08506.

Işık, A., Çiltaș, A., ve Bekdemir, M. (2018). Matematik eğitiminin gerekliliği ve önemi. Atatürk Üniversitesi Kazım Karabekir Eğitim Fakültesi Dergisi, 17, 174-184.

Kaplan, A., Altaylı, D. ve Öztürk, M. (2014). Kareköklü sayılarda karşılaşılan kavram yanılgılarının kavram karikatürü kullanılarak giderilmesi. Uludağ Üniversitesi Eğitim Fakültesi Dergisi, 27(1), 85-102.

Katipoğlu, M., Eken, Z. ve Körbay, M. (2017). Matematik öğretiminde eğlence ve mizah içeren karikatürlerin kullanılmasının öğrencilerin matematik başarısına ve matematik kaygısına etkisi. International Journal of Education, Science and Technology. 3(1), 32-45.
Kaya, D. (2017). 7. sınıf öğrencilerinin cebirsel düşünme düzeyleri ile becerilerinin incelenmesi. Bartın Üniversitesi Eğitim Fakültesi Dergisi, 6(2), 657-675. doi:10.14686/ buefad.309000.

Kerr, A. W., Hall, H. K., \& Kozub, S. A. (2002). Doing statistics with SPSS. Sage.

Skemp, R. (1986). The psychology of learning mathematics. U.K.: Penguin Books.

Şengül, S. ve Cantimer, G. G. (2018). Öğrenciler tam sayı kavramından ne anlıyor? Öğrenci gözüyle tam sayılarda kavram imajı. International Journal of Social Science, 65. 29-50. doi: 10.9761/JASSS7444

Tekerek, B. ve Cebesoy, Ü. B. (2017). An interdisciplinary study on 8th grade middle grade student's learning difficulties of line graphs in heat-temperature unit. EFMED, 11(2), 307-332.

Toor, A., \& Mgombelo, J. (2015, February). Teaching mathematics through storytelling: Engaging the'being'of a student in mathematics. CERME 9 - Ninth Congress of the European Society for Research in Mathematics Education, Charles University in Prague, Faculty of Education; ERME, Feb 2015, Prague, Czech Republic. pp.3276-3282. ffhal-01289881f

Ülgen, G. (2001). Kavram geliştirme kuramlar ve uygulamalar. İstanbul: Pegem Akademi.

Ünüvar, E. (2019). Matematik Öğretiminde karikatürlerle zenginleştirilmiş eğitsel matematik hikâyelerinin Kkullanılmasının öğrencilerinin matematik başarısına etkisi (Yüksek lisans tezi). Akdeniz Üniversitesi Eğitim Bilimleri Enstitüsü.

Yavuz, S. ve Büyükekşi, C. (2011). Kavram karikatürlerinin ısı-sıcaklık kavramlarının öğretiminde kullanılması. Karaelmas Fen ve Mühendislik Dergisi, 1(2), 25-30.

Yenilmez, K. ve Bağdat, O. (2014). Yedinci sınıf öğrencilerinin tam sayılarla işlemler konusundaki öğrenme güçlükleri. I. Avrasya Eğitim Araştırmaları Kongresi Bildiri Özetleri Kitapçı̆̆ı, 631-632.

Yıldırım, C. (2017). Matematiksel düşünme. İstanbul: Remzi Kitabevi.

Yıldırım, F. S. (2017). Öğretmenlerin yapılandırmacı öğrenme ortamı hazırlama becerilerinin bazı değișkenler bakımından incelenmesi. Eğitim, Bilim ve Teknoloji Araştırmaları Dergisi, 2(1), 15-24.

Yiğit, Ö. E. ve Erdoğan, T. (2008). Sosyal bilgiler dersinde uygulanan öyküleştirme yönteminin ilköğretim altıncı sınıf öğrencilerinin yaratıcı düşünme düzeylerine etkisi. Çukurova Üniversitesi Sosyal Bilimler Enstitüsü Dergisi, 17(3), 399-416.

Young, L. K. \& Booth, J. L. (2015). Student magnitude knowledge of negative numbers. Journal of Numerical Cognition, 1(1), 38-55. doi:10.5964/jnc.v1i1.7. 


\section{Ek-Hikâye ve Karikatür Örnekleri}

Hikâye Örneği: "Tam Sayılar Minibüsü"

Tam Sayılar Minibüsü

Şipşak -8 ile birlikte sayılar dünyasını keşfetmeye devam ediyordu.-8 ona, birlikte güzel bir yolculuk yapacaklarını, ama yolun uzun olması sebebiyle tam sayılar minibüsüne binmeleri gerektiğini söylemişti. Durağa geldiklerinde sıralanmış bekleyen sayıları gören Şipşak heyecanla -8'e dönüp:

- Hadi -8, hemen sıraya girelim; önlerden yer kapmalıyız.

- Aaa hayır, bu hiçbir işe yaramaz.

- Nasıl yani?

- Minibüste rastgele oturamayız, içerde en büyükten en küçüğe sıralanarak otururuz.

- Gerçekten mi!

- Evet, sırada bekleyen tam sayılardan pozitif tam sayılar önce girecekler, onlar bizden daha büyükler; daha sonra ise bizler gireceğiz, negatif tam sayılar.

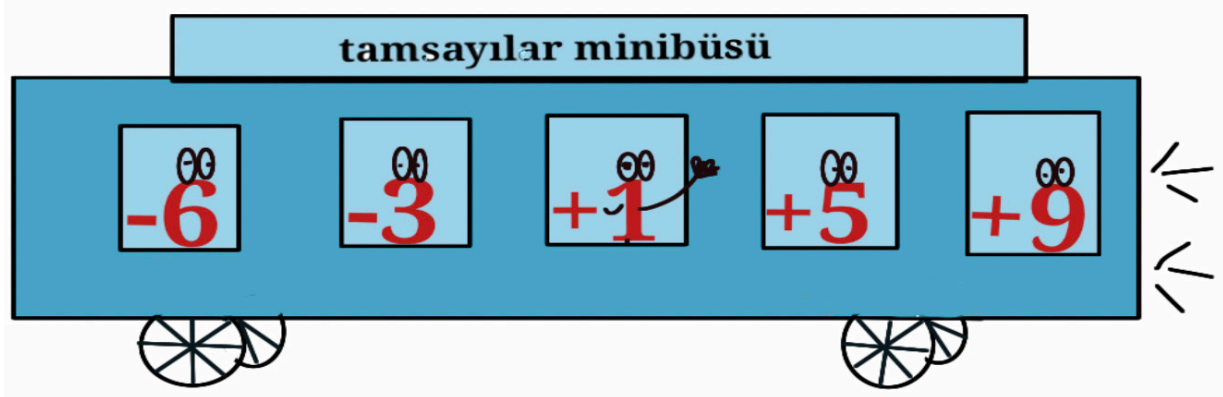

Nihayet minibüse binme sırası onlara gelmişti. -8 biraz yana sıkışıp yanına Şipşak ı da oturtmuştu. Şipşak arka koltuklarında ona gülümseyen -10 sayısını gördüğünde çok şaşırmıştı.

- Aaa -10; senin daha önde oturman gerekmiyor muydu?
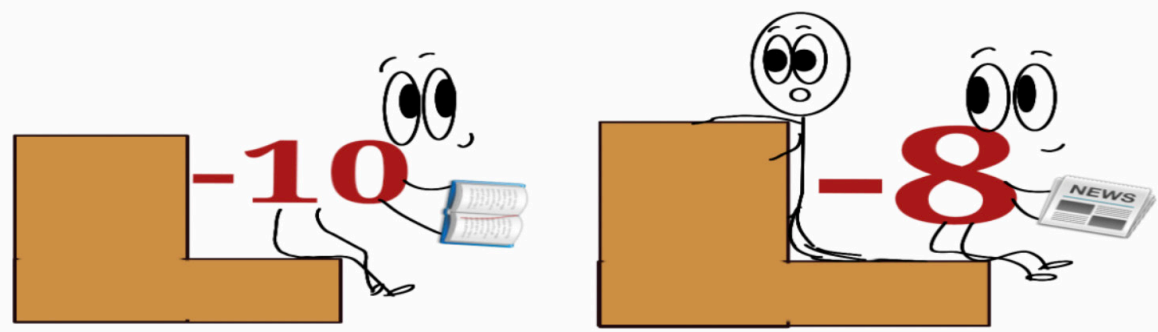

- Hayır evlat, ben doğru yerdeyim. -8 benden daha büyük.

Şipşak'ın kafası karışmıştı. -8 hemen açıkladı:

- Bak Şipşak, sayılar dünyasında sayılar sayı doğrusunda soldan sağa doğru gittikçe büyürler. Pozitif tam sayılar sıfırdan, sıfır da negatif tam sayılardan büyüktür. Sayı doğrusunda ben -10' dan daha sağda olduğum için ondan daha büyüğüm. Bak ön koltukta oturan -3 ise benden daha büyük.

-8 anlatmaya devam ederken minibüsteki -1 ve +1 sayılarının yükselen sesleri herkesin dikkatini çekmişti.

+1: Sen kendini ne zannediyorsun, kalk yerimden!

-1: Ben en büyük negatif tam sayıyım, kalkamam.

+1: Ben pozitifim ve senden daha büyüğüm, hemen kalk. Bacak bacak üstüne atmış şuna bak! Biraz büyüklere saygın olsun yahu! 
-1 sinirle oturduğu yerden kalktı:

- Kalkıyorum ama şunu bil! Sen benden büyük olabilirsin ama en küçük pozitif tam sayısın, üzülüyorum sana.

Şipşak sayıların tartışmalarını dinlerken minibüs çoktan hareket etmeye başlamıştı bile. Onları bekleyen yeni bir maceraya doğru gidiyorlardı.

Karikatür Örnekleri

'Sıfırı Üzmeyelim'

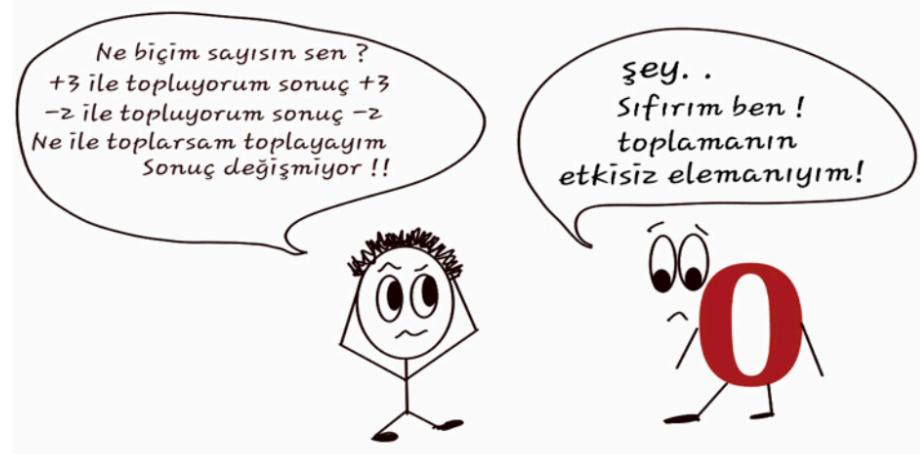

'Sadece Pozitif Olacaksın'

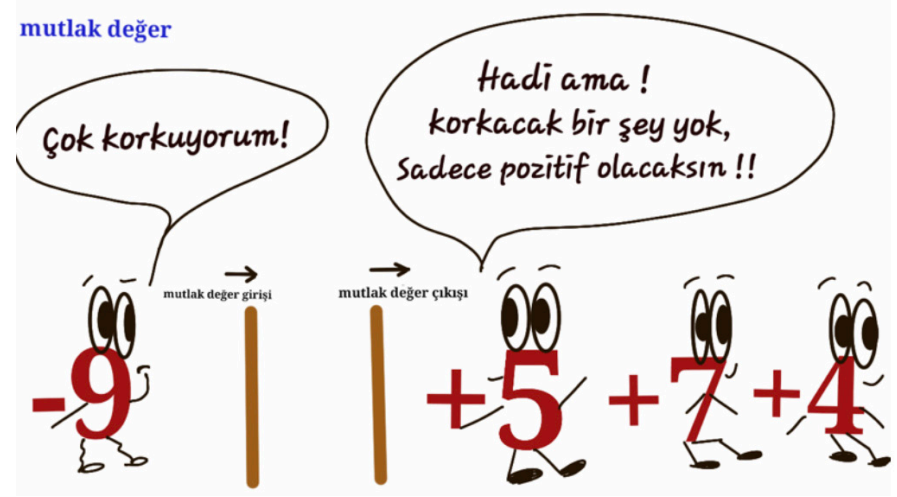

